\title{
Antioxidant Effect of Phycocyanin on Oxidative Stress Induced with Monosodium Glutamate in Rats
}

\author{
Telma Elita Bertolin ${ }^{*}$, Daniele Farias ${ }^{2}$, Cíntia Guarienti ${ }^{2}$, Fernanda Tais Souza Petry ${ }^{2}$, \\ Luciane Maria Colla $^{2}$ and Jorge Alberto Vieira Costa ${ }^{3}$ \\ ${ }^{I}$ Departamento de Ciências Fisiológicas; Instituto de Ciências Biológicas; Universidade de Passo Fundo; Passo \\ Fundo - RS - Brasil. ${ }^{2}$ Laboratório de Fermentação; Centro de Pesquisa Nutrição; Universidade de Passo Fundo; \\ Passo Fundo - RS - Brasil. ${ }^{3}$ Laboratório de Engenharia Bioquímica; Universidade Federal do Rio Grande; Rio \\ Grande - RS - Brasil
}

\begin{abstract}
The objective of this work was to study the antioxidant effect of phycocyanin on the oxidative stress induced by monosodium glutamate in the rats. The tests were performed with 32 rats of Wistar breed, divided into four groups, which were administered saline solution of phycocyanin, monosodium glutamate and monosodium glutamate plus phycocyanin. Sulfhydryl groups and the secondary substances derived from lipid oxidation were determined through the level of TBA. The evaluation of these values and the level of sulfhydryl showed that the administration of phycocyanin presented significant antioxidant effect $(p<0.05)$ reducing the oxidative stress induced by the monosodium glutamate in vivo.
\end{abstract}

Key words: antioxidant, oxidative stress, phycocyanin

\section{INTRODUCTION}

The cells respiration, the mitochondrial oxidative stress and lipid peroxidation are considered free radicals sources and may cause in cell damage. The oxygen reactive species are formed in vivo and are powerful oxidant agents that can damage the DNA and other biomolecules (Salvador et al., 2004; Halliwell, 2007). The most recent studies show that oxidative stress plays an important role in several clinical conditions such as cancer, neoplasms, diabetes, atherosclerosis, neurodegenerative diseases, chronic inflammation and damage caused by ischemia (Salvador et al., 2004; Lin and Beal, 2006).
Polyunsaturated fatty acids (PUFAs) that are usually present in the cells membranes, are easily oxidized by the free radicals, leading to lipid peroxidation. This could modify the permeability of the cells, which could cause cellular death and/or the oxidation of lipoproteins (Garcez et al., 2004). The oxidation of lipoproteins causes changes in the lipid and protein structures, leading to lipid peroxidation. Amongst the products formed, the reactive oxygen species, cause oxidative damage (Sohal, 2002; Abdalla and Sena, 2009). Oxidative damage caused to proteins could promote alterations in their physicochemical properties, and thus, affect the receptors function, enzymes, antibodies, transport

*Author for correspondence: telma@upf.br 
proteins, alterations in the DNA, among others (Crabtree, 2003; Halliwell, 2007).

Among the final products of lipid peroxidation, there are low molecular weight compounds such as hydrocarbons (ethane and pentane) and aldehydes, such as malondialdehyde (MDA), which can damage the proteins, DNA, RNA and other biomolecules (Esterbauer and Cheeseman, 1990).

The test of thiobarbituric acid (TBA) is a method largely used to measure the peroxidation of fatty acids and of cell membranes. MDA is a threecarbon dialdehyde, which reacts with 2thiobarbituric acid producing a compound which presents red color, measured in spectrophotometer with wavelengths between 500 and $550 \mathrm{~nm}$ (Osawa, 2005). The loss of sulfhydryl groups is one of the main oxidative damages in peptide chains. The method for the determination of the thiol groups is widely used to measure the formation of disulfide bridges in the proteins and it is quantified through the value of sulfhydryl groups (Griffith, 1999; Dickinson and Forman, 2002a; Dickinson and Forman, 2002b). The monosodium glutamate is a substance commonly used in the food industry to enhance the food flavor. However, this substance is neurotoxic and the excess of monosodium glutamate in the brain allows high affluence of calcium inside the neuronal cell, providing the formation of free radicals (FR) with cell death (Natali, 2001; Cesaretti, 2006). The oxidative stress damage is minimized by the antioxidant defense system and can be classified as natural or synthetic (Jones, 2008; Halliwel, 2007). Nowadays, there is a growing interest in the natural antioxidants due to their low toxicity. There is growing concern on the use of the synthetic antioxidants due to the harmful effects caused by their high doses, low solubility and toxic effects (Duran, 1993; Galvão, 2008).

The use of natural antioxidants and dietary supplements have been the object of many studies, with several reports that the phenolic compounds not only increase the food shelf-life, but also act as antioxidants in many biological systems (Milié et al., 1998; Estrada et al., 2001; Colla, 2008; Bertolin, 2009).

Spirulina (Arthrospira) has been studied extensively not only due to its potential as protein source, but also due to its therapeutic potential in several areas, including the ability to prevent and inhibit the cancer, reduce the blood cholesterol, stimulate the immunological system, reduce the renal toxicity of pharmaceutical products and toxic metals, promote protection against the damage generated by radiation and the damage caused by oxidative stress (Belay, 2002; Bertolin, 2009). S. platensis is a filamentous photoautotrophic cyanobacteria mainly used as a dietary supplement (Henrikson, 1994) due to its high protein content $(55-70 \%)$, sugar (12-25\%), essential fatty acids (18\%), vitamins and minerals (Sanchez et al., 2003). Spirulina is legally authorized as a dietary supplement in Europe, Japan and United States by FDA (Food and Drug Administration), as it does not cause any toxic effects on the organism (Belay et al., 1993; Von Der Weid et al., 2000). In Brazil, ANVISA (National Agency of Sanitary Vigilance) allows its commercialization as long as the final product where the microorganism is be added is properly registered (Brasil, 2008).

Spirulina contains carotenoid, especially betacarotene and zeaxanthin, besides the phycocyanin (Estrada et al., 2001) and phenolic compounds (Colla et al., 2008), which are known for their antioxidant activity. The phycocyanin and allophycocyanin are the pigments that can be found in thylakoids of cyanobacteria, such as $S$. platensis, and are studied due to their ability to react with reactive substances generated during the oxidative process (Estrada, 2001).

The objective of this work was to study the antioxidant effect of phycocyanin on oxidative stress induced by monosodium glutamate in the rats.

\section{MATERIAL AND METHODS}

A total of 32 male sub-adults rats (Wistar breed) were used, with a life period of 50 days, (Rattus norvegicus albinos, Wistar). The rats were distributed in four experimental groups. Each group was composed by eight animals, where four of them were used in the experiment of dosage of the malonaldehyde by the thiobarbituric acid (TBA) content and four for the determination of sulfhydryl groups. The animals were submitted to the treatments over a period of eight days.

The treatments consisted of the administration of a phycocyanin solution by gavage, as attenuator of oxidative stress, and solution of monosodium glutamate, intraperitoneal, as a promoter of oxidative stress (Farombi and Onyema, 2006). 
The administered dose of phycocyanin was calculated with a reference to the daily intake of $S$. platensis nominated for a man with an average weight of about $60 \mathrm{~kg}$ was $5 \mathrm{~g} / \mathrm{d}$. This suggested that for an animal of about $300 \mathrm{~g}$, the optimal dosage would be $0.025 \mathrm{~g} / \mathrm{d}$ of Spirulina. According to Estrada et al. (2001), the amount of phycocyanin in $S$. platensis was approximately $20 \%$ dry weight. Thus, it was $5 \mathrm{mg} / \mathrm{d}$ dosage of phycocyanin for each rat.

The biomass of Spirulina platensis was obtained from the Laboratory of Biochemical Engineering of the Food Engineering Course, FURG - RS. The phycocyanin was extracted with water at 4 ${ }^{\circ} \mathrm{C}$. The suspensions were submitted to the cycles of freezing and defrosting, followed by centrifugation to separate the biomass. The supernatant was used for the quantification of phycocyanin by reading in the spectrophotometer at $640 \mathrm{~nm}$ and comparing it to a standard curve previously prepared. The dose of monosodium glutamate was given to the rats, intraperitoneally, at a concentration of $4 \mathrm{mg} / \mathrm{body} \mathrm{g}$, using references from Diniz et al (2004).

The four experimental groups were divided into control group $\left(\mathrm{G}_{1}\right)$, phycocyanin group $\left(\mathrm{G}_{2}\right)$, glutamate group $\left(\mathrm{G}_{3}\right)$ and phycocyanin + glutamate group $\left(\mathrm{G}_{4}\right)$. During the eight days period of treatment, the groups $G_{2}$ and $G_{4}$, received phycocyanin by gavage. The groups $\mathrm{G}_{1}$ and $\mathrm{G}_{3}$ received saline solution, also by gavage, to follow a pattern for all the procedures conducted with the animals under the treatment. The animals of the groups $\mathrm{G}_{3}$ and $\mathrm{G}_{4}$ at the eighth day of treatment were administered monosodium glutamate and saline solution intraperitoneally. To promote the same conditions and interferences, the groups $G_{1}$ and $G_{2}$ received saline solution intraperitonially. One hour after the application of monosodium glutamate and the saline solution, the animals were decapitated using a guillotine and the hippocampus was removed to test the lipid peroxidation, through the method of reactive substances thiobarbituric acid TBA, described by Esterbauer and Cheeseman (1990). The concentration of total sulfhydryl groups was determined according to Aksenov and Markesbery (2001). The protein concentration was measured by Lowry method (1951), using bovine serum albumin as standard.

\section{RESULTS AND DISCUSSION}

The results of the malonaldehyde through the method of thiobarbituric acid (TBA), expressed as nmol of malondialdehyde per mg protein (nmol $\mathrm{MDA} / \mathrm{mg}$ protein) are presented in Table 1 .

$\underline{\text { Table } 1 \text { - TBA levels for treatments (nmol MDA/mg protein) }}$

\begin{tabular}{cc}
\hline Treatment & TBA \\
\hline $\mathrm{G}_{1}$ & $1.43 \pm 0.30^{\mathrm{ab}}$ \\
$\mathrm{G}_{2}$ & $0.64 \pm 0.22^{\mathrm{a}}$ \\
$\mathrm{G}_{3}$ & $1.80 \pm 0.09^{\mathrm{b}}$ \\
$\mathrm{G}_{4}$ & $0.72 \pm 0.21^{\mathrm{a}}$ \\
\hline
\end{tabular}

Different letters represent significative difference on a 5\% significance level.

$\mathrm{G}_{1}$ : control; $\mathrm{G}_{2}$ : phycocyanin; $\mathrm{G}_{3}$ : glutamate; $\mathrm{G}_{4}$ : glutamate + phycocyanin.

The variance analysis of these results showed a significant difference between the treatments $(\mathrm{p}<$ 0.05). The rats treated with glutamate $\left(\mathrm{G}_{3}\right)$ presented the highest value of malonaldehyde, 1.80 ( \pm 0.09) nmol MDA/mg protein, higher compared to the value found for the control group $\left(\mathrm{G}_{1}\right)$, which presented $1.43( \pm 0.30)$ nmol $\mathrm{MDA} / \mathrm{mg}$ protein. The statistical comparison of the average results obtained for these treatments $\left(\mathrm{G}_{1}\right.$ and $\left.\mathrm{G}_{3}\right)$ showed that these values were statistically equal to each other at a confidence level of $95 \%$. On the other hand, the results of the $\mathrm{G}_{3}$ group differed statistically $(\mathrm{p}<0.05)$ from the results of $G_{2}$ and $G_{4}$, which were administered phycocyanin, and these groups showed the lowest values for the rate of TBA from $0.64( \pm 0.22)$ and $0.72( \pm 0.72) \mathrm{nmol} \mathrm{MDA} / \mathrm{mg}$ protein, respectively.

The results showed that monosodium glutamate was a very reactive substance and induced lipid peroxidation, leading to formation of reactive substances of low molecular weight, such as MDA, measured by the TBA test. Nonetheless, it also evidenced the antioxidant capability of phycocyanin $\left(\mathrm{G}_{2}\right.$ and $\mathrm{G}_{4}$ groups), which inhibited 
lipid peroxidation induced by the administration of monosodium glutamate.

Similar results were found by Farombi and Onyema (2006), who found that the monosodium glutamate when was administered intraperitoneally at $4 \mathrm{mg} / \mathrm{g}$ of body weight dose, increased the formation of malondialdehyde (MDA) in the rat's liver and brain. Farombi and Onyema (2006) showed significant reduction of the TBA levels of the rats treated with monosodium glutamate, with simultaneous administration of vitamin $\mathrm{C}$, vitamin $\mathrm{E}$ and queracetin. Rimbau et al. (1999) reported the antioxidant potential of the protein Cphycocyanin extracted from $S$. platensis and showed that the metabolites of this protein had the ability to cross the blood-brain barrier, thereby conferring a protective effect of oxidative stress on the hippocampus of the rats.

Table 2 presents the results on the effect of shulfhydryl groups for the animals submitted to different treatments.

Table 2 - Concentration of sulfhydryl groups for the treatments. ( $\mu \mathrm{mol} / \mathrm{g}$ protein).

\begin{tabular}{cc}
\hline Treatment & Sulphydryl \\
\hline $\mathrm{G}_{1}$ & $11.69 \pm 3.16^{\mathrm{a}}$ \\
$\mathrm{G}_{2}$ & $3.91 \pm 1.31^{\mathrm{a}}$ \\
$\mathrm{G}_{3}$ & $44,68 \pm 7,06^{\mathrm{b}}$ \\
$\mathrm{G}_{4}$ & $13.20 \pm 6.37^{\mathrm{a}}$ \\
\hline
\end{tabular}

Different letters represent significative difference $(\mathrm{p}=0.05)$.

$\mathrm{G}_{1}$ : control; $\mathrm{G}_{2}$ : phycocyanin; $\mathrm{G}_{3}$ : glutamate; $\mathrm{G}_{4}$ : glutamate + phycocyanin .

According to the variance analysis of these results, the treatments presented significant difference $(\mathrm{p}<0.05)$. Table 2 showed that the highest value found for the concentration of sulfhydryl groups was for the monoglutamate group $\left(\mathrm{G}_{3}\right)$, which presented a response of 44.68 $( \pm 7.06) \mu \mathrm{mol} / \mathrm{g}$ protein, a value statistically different from the other treatments $\left(G_{1}, G_{2}\right.$ and $\mathrm{G}_{4}$ ).

The control group $\left(\mathrm{G}_{1}\right)$, phycocyanin $\left(\mathrm{G}_{2}\right)$ and phycocyanin + monoglutamate $\left(\mathrm{G}_{4}\right)$ were statistically equal $(\mathrm{p}<0.05)$ for the levels of sulfhydryl, and the lowest level was obtained for the phycocyanin group $\left(\mathrm{G}_{2}\right)$, which presented 3.91 $( \pm 1.31) \mu \mathrm{mol} / \mathrm{g}$ protein, demonstrating again the antioxidant potential of this substance.

There are several report on clinical studies in which the reactive oxygen species (ROS) or oxygen free radicals (OFR) has been acknowledged as pathophysiological elements, highlighting among them the ischemiareperfusion syndromes such as myocardial infarction, intestinal ischemia, necrotizing enterocolitis, cerebral ischemia (Willet, 1995). The involvement of ROS as one of the mechanisms involved in the injury and cell death, mainly when it comes to injury due to ischemia of tissues and organs has been shown by different authors (McCord, 1985; Hansson et.al., 1982; Cross, 1987). The reactive oxygen species, due to its oxidative priorities can act directly on lipid components of cell membranes tending to generate chain reactions to produce the free radicals, resulting in an amplification of the process which ends with a destructive effect on the cell. This phenomenon can also be processed indirectly through the peroxidative lipid radicals and other products of the lipid fragmentation which, alone are oxidant agents (Bulkey, 1983).

Cysteines, the sulfhydryl (SH)-containing amino acid residues in proteins, are susceptible targets for a variety of pro-oxidants. Mammalian cells from different tissues, including the brain, posses a system that regulates the redox status of cellular thiols and protects SH-containing proteins from excessive oxidation. It includes low molecular weight donors of SH groups, enzymes and antioxidants, which catalyze the reduction of $\mathrm{SH}$ groups in proteins and detoxify the pro-oxidants by conjugation with glutathione. In this way, the antioxidant system plays a central role in thiol status in the brain, helping in the protection against oxidant agents (Aksenov and Markesbery, 2001).

Interestingly, there is no report on the work as described above. However, similar results for the antioxidant defense system to oxidative damage were found. Aksenov and Markesbery (2001) studied the increased level of oxidative modifications in proteins, lipids, and nucleic acids in the brain of patients with Alzheimer's disease, and they found that the total thiol content was 
increased by $\sim 20 \%$ in the patients with Alzheimer in the cerebellum, indicating that the oxidative agents promoted the damage irreversible in the brain. Other investigators have suggested that the synthesis of SH-containing could be increased as a response to oxidative stress in the brain causing disease, and the antioxidant agents could acted preventing this situation (Palmer, 1999). Corwin and Schwarz (1963) studied the properties of $\alpha$-tocopherol in the presence of reactive free radicals and found that a tocopherol defense mechanism was involved in the protection of essential sulfhydryl groups since the oxidation of tocopherol in the systems containing sulfhydryl groups protected the cells of oxidative damage.

The administration of monosodium glutamate promoted an elevation on the TBA and sulfhydryl groups, which proved they acted as an oxidative stress promoter. However, the damage caused was minimized by the action of the phycocyanin pigment, showing its capacity to acting as an antioxidant substance. Thus, it was possible to inhibit the beginning of the oxidative process promoted by a number of precursors and, consequently the production of free radicals, preventing thus several clinical complications generated by these processes.

The results showed that the antioxidant potential of the phycocyanin present in cyanobacterium $S$. platensis and also indicated that the amount administered to the rats $(5 \mathrm{mg} / \mathrm{d})$ was sufficient to reduce the oxidative damage caused by monosodium glutamate in vivo. The results were confirmed by the TBA values, which decreased from $1.80 \pm 0.09\left(\mathrm{G}_{3}=\right.$ monoglutamate $)$ to $0.64 \pm$ $0.22 \mathrm{nmol} \mathrm{MDA} / \mathrm{mg}$ protein $\left(\mathrm{G}_{2}=\right.$ phycocyanin $)$ and by the levels of sulfhydryl, decreasing from $44.68 \pm 7.06\left(\mathrm{G}_{3}\right)$ to $3.61 \pm 1.31 \mu \mathrm{mol} / \mathrm{g}$ protein $\left(G_{2}\right)$. The decrease in the TBA values and the levels of sulfhydryl in the $\mathrm{G}_{2}$ group (phycocyanin) compared to the control group showed that the $\mathrm{t}$ phycocyanin could be administered not only to reduce, but also to prevent the oxidative damage through the possibility of incorporation of this substance as a dietary supplement.

\section{NOTE}

For the experiments, the research project was first submitted to and approved by the Ethics Committee at University of Passo Fundo.

\section{REFERENCES}

Abdala, D. S. P.; Sena, K. C. M. (2008), Biomarcadores de peroxidação lipídica na arteroclerose. Rev. Nutri., Campinas, 21 (6), 749-756

Aksenov M. Y., Markesbery W. R. (2001), Changes in thiol content and expression of glutathione redox system genes in the hippocampus and cerebellum in Alzheimer's disease. Neurosci. Lett. 302, 141/145

Belay A, Ota Y, Miyakawa k, Himamatsu H. (, 1993), Current knowledge on potential health benefits of Spirulina. J Appl Phycol; 5, 235-41

Belay, A (2002), The Potential Application of Spirulina (Arthrospira) as a Nutritional and Therapeutic Supplement in Health Management. The Journal of the American Nutraceutical Association, 5 (2), 27-48

Bertolin, T.E.; Pilatti, D.; Giacomini, A.C.; Bavaresco, C.; Colla, L.M.; Costa, J.A.V. (2009), Effect of Microalga Spirulina platensis (Arthrospira platensis) on Hippocampus Lipoperoxidation and Lipid Profile in Rats with Induced Hypercholesterolemia. Braz Arch Biol Technol. 52 (5), 1253-1259

Bonnefoy, M., Drai, J., Kostka, T. (2002), Antioxidants to slow aging, facts and perspectives. Presse. Med. 31 (25), 1174-84

Brasil. Agência Nacional de Vigilância Sanitária. VII Lista dos novos ingredientes aprovados - Comissões Tecnocientíficas de Assessoramento em Alimentos Funcionais e Novos Alimentos. Disponível em URL: http://www.anvisa.gov.br/alimentos/comissoes/novo s_ingredientes.htm. [2008]

Bulkey, G.B. (1983), The role of oxygen free radicals in human disease processes. Surgery, 94 (3): 407-11

Cabtree, M., Hao, G., Gross, S. S. (2003), Detection of cysteine S-nitrosilation and tyrosine 3-nitration in kidney proteins. Methods Mol. Med., 86, 373-384

Cesaretti, M.L.R.; Junior, O.K. (2006), Modelos Experimentais de Resistência à Insulina e Obesidade: Lições Apreendidas. Arq. Bras. Endocrinol. Metab. 50 (2)

Colla, L.M.; Muccillo-Baisch, A.L.; Costa, J.V. (2008), Spirulina platensis effects on the levels of total cholesterol, HDL and triacylglycerols in rabbits fed with a hypercholesterolemic diet. Braz Arch Biol Technol.; 51 (2), 405-11

Corwin, L. M., Schwarz, K. Relation of tocopherol to enzyme sulfhydryl sites. Arch. Biochem. Biophys; 100, 385-92

Cross, C.E.; Halliwell, B.; Borish, E.T.; Pryor, W.A.; Ames, B.; Saul, R.L.; Mccord, J.M. (1963), Harman, D. (1987), Oxygen radicals and human disease. Ann. Inter. Med., 107 (4), 526-45

Dickinson, A. D., Forman, J. H. (2002a), Glutathione in defense and signaling lessons from a small tiol. J. Ann. N. Y. Acad. Sci. 973, 488-504 
Dickinson, D. A.; Forman, H. J.; (2002b.), Cellular glutathione and thiols metabolism Biochem. Pharmacol. 64, 1019-26

Diniz, Y.S.et al. (2004), Toxicity of hipercaloric diet and monosodium glutamate: oxidative stress and metabolic shifting in hepatic tissue. Food and Chemical Toxicology, 42, 313-319

Duran, R.M.; Padilla, R.B. (1993), ccurring antioxidante de los compuestos fenolicos. Grasas e Aceites, 44, (2), 101-106

Esterbauer, H. and Cheeseman, K., (1990), Determination of aldehydic lipid peroxidation products: malonaldehyde and 4-hydroxynoneal. Method. Enzymol., 186, 407-408

Estrada, J. E. P.; Bescós, P. B.; Fresno, A. M. V. (2001), Antioxidant activity of different fractions of Spirulina platensis protean extract. Il Farmaco, 56, 497-500

Farombi E. O., Onyema O.O. (2006), Monomonosodium glutamate-induced oxidative damage and genotoxicity in the rat: modulatory role of vitamin C, vitamin E and quercetin. Hum Exp Toxicol. 25(5), 251-9

Galvão, E. L.; Silva, D. C. F.; Ilva, J. O.; Moreira, A. V. B.; Sousa, E. M. B. (2008), Avaliação do potencial antioxidante e extração subcrítica do óleo de linhaça. Ciênc. Tecnol. Aliment. Campinas, 28 (3), 551-557

Garcez, M., Bordin, D., Peres, W., Salvador, M. (2004), Radicais livres e espécies reativas, Radicais livres e a resposta celular ao estresse oxidativo, organização Mirian Salvador e João A. P. Henriques, Canoas: Ed. Ulbra,

Griffith, O. W.; (1999), Biologic and pharmacologic regulation of mammalian glutathione synthesis, Free Radical Biol. Med. 27, 922

Halliwell, B.; Gutteridge J.M.C. (1999), Free radicals in biology and medicine. $3^{\text {rd }}$ ed. New York: Oxford,

Halliwell, B. (2007), Oxidative stress and cancer: have we moved forward? Biochem. J. 401, 1-11

Hansson, R.; Gustafsson, B.; Jonsson, O.; Lundstan, S.; Petterson, S.; Schersten, T.; Waldenström, J. (1982), Effect of xanthine oxidase inhibition on renal circulation after ischemia. Transplant. Proc., 14 (1), $51-8$

Henrikson, R. (1994), Microalga Spirulina Superalimento del futuro. Barcelona: Ediciones S.A. Urano, ISBN 84-7953-047-2

Jones, D.P. (2008), Radical-free biology of oxidative stress. Am. J. Physiol. Cell Physiol. 295, C849-C868

Lin, M.T.; Beal, M.F. (2006), Mitochondrial dysfuinction and oxidative stress in neurodegenerative diseases. Nature. 443, 787-95
Löwry, O.H.; Rosebrough, M.J.; Farr, A.L.; Randall, R.J. (1951), Protein measurement with the foline reagent. J. Biol. Chem., 193, 265

Lu, S. C. (1999), Regulation of hepatic glutathionesynthesis: current concepts and controversies. Faseb J. 13 (10), 1169-1183

Milié, B.L.; Djilas, S.M. (1998), Canadavnovié-Brunet, J.M. Antioxidative activity of phenolic compounds on the metal-ion breakdown of lipid peroxidation system. Food Chemistry, 61, 443-447

Mccord, J.M. Oxygen-derived free radicals in postischemic(1985), tissue injury. N. Engl. J. Med., 312 (3), 159-63

Natali, M. R. M.; Soares, a; Schoffen, J. P. F. E Gouveia, E. M. D. Efeitos do tratamento com glutamato monossódico nos neurônios do plexo mioentérico do íleo de ratos (Rattus norvegicus). Universidade Estadual de Maringá, Maringá - PR Brasil.

Osawa, C. C.; Felicio, P. E. ; Goncalves, L. A. G. Teste de TBA aplicado a carnes e derivados: métodos tradicionais, modificados e alternativos. Química Nova, São Paulo, 28 (4), 655-663, 2005.

Palmer, A.M. (1999), The activity of pentose phosphate pathway is increased in response to oxidative stress in Alzheimer's disease. J. Neural. Transm., 106, 317-328

Rimbau, V.; Camins, A.; Romay, C.; González, R.; Pallàs, M. (1999), Protective effects of Cphycocyanin against kainic acid-induced neuronal damage in rat hippocampus. Neuroscience Letters, 276, 75-78

Salvador, M., Poletto, N. P., Andreazza, A. C., Soares, D. G., (2004), Estresse oxidativo e doenças, Radicais livres e a resposta celular ao estresse oxidativo, organização Mirian Salvador e João A. P. Henriques, Canoas: Ed. Ulbra

Sánchez, M.; Bernal-Castillo, J.; Rozo, C.; Rodríguez, I. Spirulina (Arthrospira): An Edible

Microorganism.(2003), A Review. Revista Universitas Scientiarum, $\mathbf{8}$

Sohal, R. S., Dubey, A., Orr, W.C. (1993), Protein oxidative damage is associated with life expectancy of houseflies. Pro. Natl. Acad. Sci. USA, 90, 72557259

Von Der Weid D, Dillon JC, Falquet J. (2000), Malnutrition: a silent massacre. Geneve: Antenna Technology; $13 \mathrm{p}$.

Willet, K.; Macedo, D.V.; Detry, O.; Evens, A.; Silva, L.P.; Sluse, F.E. (1995), Mitochondrial oxidative phosphorylation injuries 738 ccurring in situ and in vivo. Transplant. Proc., 27 (5), 2827-8. 